\title{
Pengaruh Profitabilitas, Kebijakan Utang, dan Kebijakan Dividen Terhadap Nilai Perusahaan
}

\author{
I Gede Eka Kurniawan ${ }^{1}$ \\ Fakultas Ekonomi dan Bisnis \\ Universitas Udayana, Indonesia. \\ Email: gd.ekakurniawan@yahoo.com
}

\author{
I Nyoman Wijana Asmara \\ Putra $^{2}$ \\ Fakultas Ekonomi dan Bisnis \\ Universitas Udayana, \\ Indonesia.
}

\begin{abstract}
ABSTRAK
Tujuan penelitian ini adalah untuk menguji pengaruh profitabilitas, kebijakan utang, dan kebijakan dividen terhadap nilai perusahaan. Metode pengambilan sampel yang digunakan adalah purposive sampling dengan jumlah sampel yang diperoleh sebanyak 14 perusahaan. Teknik analisis data yang digunakan dalam penelitian ini adalah analisis regresi linear berganda. Berdasarkan hasil analisis ditemukan bahwa profitabilitas berpengaruh positif terhadap nilai perusahaan. Hal ini menunjukkan bahwa semakin meningkat profitabilitas maka nilai perusahaan akan meningkat. Kebijakan utang tidak berpengaruh terhadap nilai perusahaan. Hal ini menunjukkan bahwa tinggi rendahnya rasio utang terhadap ekuitas, tidak berimplikasi pada tinggi rendahnya nilai perusahaan. Kebijakan dividen berpengaruh positif terhadap nilai perusahaan. Hal ini menunjukkan bahwa meningkatnya pembayaran dividen akan meningkatkan nilai perusahaan.
\end{abstract}

Kata Kunci : Profitabilitas, kebijakan utang, kebijakan dividen, nilai perusahaan.

\section{The Effect of Profitability, Debt Policy, and Dividend Policy on Company Value}

\begin{abstract}
The purpose of this study is to examine the effect of profitability, debt policy, and dividend policy on firm valueThe sampling method used was purposive sampling with the number of samples obtained was 14 companies. The data analysis technique used in this study is multiple linear regression analysis. Based on the results of the analysis it was found that profitability had a positive effect on firm value. This shows that the higher the profitability, the higher the value of the company. Debt policy does not affect the value of the company. This shows that the high level of debt to equity ratio does not have implications for the high and low value of the company. Dividend policy has a positive effect on company value. This shows that increasing dividend payments will increase the value of the company.
\end{abstract}

Keywords: Profitability, debt policy, dividend policy, company value.

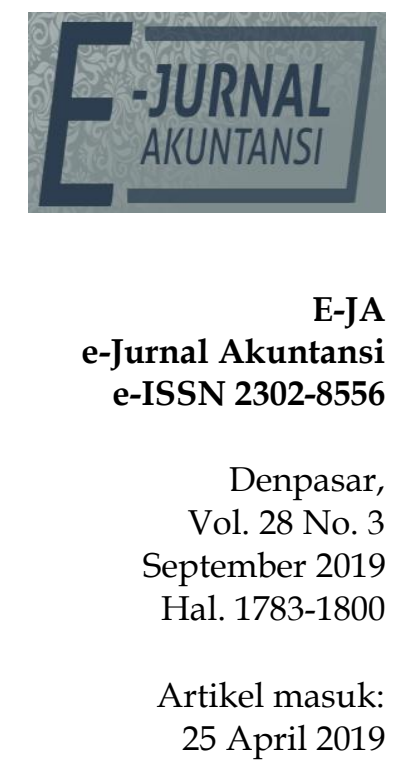

Tanggal diterima: 26 Juli 2019 


\section{PENDAHULUAN}

Bursa Efek Indonesia (BEI) adalah pusat transaksi capital market saat ini. BEI sebagai salah satu pasar modal yang dapat dijadikan alternatif pendanaan bagi semua sektor perusahaan di Indonesia. Salah satu alternatif pendanaan adalah melalui penerbitan dan penjualan saham di Bursa Efek. Sektor yang salah satu sahamnya masuk dalam BEI adalah sektor pertambangan. Terdapat 47 perusahaan yang berada di sektor pertambangan. Subsektor yang dimaksud adalah subsektor batu bara, minyak dan gas bumi, logam dan mineral lainnya dan batu-batuan. Sektor pertambangan memiliki peran penting sebagai penyedia sumber daya energi yang diperlukan bagi pertumbuhan ekonomi suatu negara, karena sektor pertambangan merupakan sumber daya alam yang dapat digunakan sebagai pembangkit listrik.

Sektor pertambangan memiliki kontribusi besar terhadap berbagai aspek mulai dari Penanaman Modal Asing (PMA), Penanaman Modal Dalam Negeri (PMDN), kegiatan ekspor, penerimaan devisa, pendapatan negara dan produk domestik bruto. Sektor pertambangan juga mampu membuka lapangan pekerjaan dan menyerap tenaga kerja yang nantinyamengurangi pengangguran dan membutuhkan dana besar sehingga untuk memenuhi dana tersebut perusahaan akan membutuhkan dana dari investor, maka dari itu penelitian ini membahas perusahaan sektor pertambangan dengan harapan dapat memberikan informasi yang lebih baik bagi penulis dan calon investor yang ingin berinvestasi dalam saham.

Pada awalnya tujuan perusahaan hanyalah berorientasi pada keuntungan yang sebanyak-banyaknya. Tujuan ini mengakibatkan perusahaan harus mengorbankan keuntungan pada jangka panjang untuk memperoleh keuntungan yang tinggi pada jangka pendek. Keuntungan jangka pendek maupun jangka panjang memiliki peranan yang penting bagi kehidupan perusahaan. Oleh karena itu saat ini tujuan utama perusahaan bukanlah untuk memperoleh laba sebesar-besarnya melainkan untuk mendapatkan nilai perusahaan yang baik. Nilai perusahaan sangat penting bagi perusahaan karena nilai perusahaan menunjukkan seberapa baik kinerja perusahaan tersebut.

Nilai perusahaan dapat dipengaruhi oleh beberapa faktor, salah satunya adalah ukuran perusahaan. Ukuran perusahaan dianggap mampu mempengaruhi nilai perusahaan karena semakin besar ukuran atau skala perusahaan maka akan semakin mudah pula perusahaan memperoleh sumber pendanaan baik yang bersifat internal maupun eksternal(Rosi, 2012). Selain itu, nilai perusahaan dapat ditentukan oleh struktur kepemilikan perusahaan. Struktur kepemilikan dipercaya mampu mempengaruhi jalannya perusahaan yang berpengaruh pada kinerja perusahaan dalam mencapai tujuan perusahaan yaitu maksimalisasi nilai perusahaan. Struktur tersebut meliputi kepemilikan institusional yang mendorong peningkatan pengawasan yang lebih optimal sehingga manajer akan diawasi dalam menentukan kebijakan finansial dan kepemilikan manajerial yang dapat mempengaruhi keputusan pencairan dana yang berupa keputusan untuk menggunakan hutang atau dengan mengeluarkan saham baru(Sadia dan Sujana, 2017).

Selain itu nilai perusahaan juga dapat dipengaruhi oleh profitabilitas, kebijakan utang, dan kebijakan dividen. Faktor-faktor tersebut dianggap penting 
karena tujuan perusahaan dapat dicapai melalui pelaksanaan fungsi manajemen keuangan dengan hati-hati dan tepat mengingat setiap keputusan keuangan yang diambil akan mempengaruhi keputusan keuangan lainnya yang nantinya berdampak terhadap nilai perusahaan. Keputusan keuangan yang harus dipertimbangkan dengan matang adalah kebijakan pendanaan dan kebijakan dividen(Hasnawati, 2005). Besar kecilnya profitabilitas juga mempengaruhi nilai perusahaan karena para stakeholders yang terdiri dari kreditur, supplier, dan juga investor akan melihat sejauh mana perusahaan dapat menghasilkan laba dari penjualan dan investasi perusahaan(Dewi dan Wirajaya, 2013).

Fluktuasi nilai perusahaan selalu terjadi pada perusahaan-perusahaan yang terdaftar di Bursa Efek Indonesia (BEI). Salah satu fenomena fluktuasi nilai perusahaan yang menarik untuk dilihat adalah fluktuasi nilai perusahaan sektor pertambangan. Pada tahun 2015, nilai perusahaan mengalami penurunan yang cukup tajam, sedangkan pada tahun 2016, nilai perusahaan mengalami kenaikan yang cukup tajam. Fluktuasi nilai perusahaan yang terjadi di perusahaan sektor pertambangan yang dapat dilihat pada Tabel 1 berikut:

Tabel 1. Fluktuasi Rata-Rata Rasio Tobin's Q, ROA, DER, dan DPR pada Perusahaan Sektor Pertambangan

\begin{tabular}{lllll}
\hline & 2014 & 2015 & 2016 & 2017 \\
\hline Tobin's Q & 1,51 & 1,03 & 1,49 & 1,46 \\
ROA & 0,07 & 0,05 & 0,08 & 0,14 \\
DER & 1,13 & 1,15 & 0,95 & 0,80 \\
DPR & 0,31 & 0,37 & 0,24 & 0,26 \\
\hline
\end{tabular}

Sumber: www.idx.co.id, 2018

Berdasarkan Tabel 1, dapat diketahui bahwa nilai perusahaan sektor pertambangan mengalami fluktuasi sejalan dengan fenomena yang telah diungkapkan sebelumnya. Selain fluktuasi yang terjadi pada nilai perusahaan juga diikuti terjadinya fluktuasi dari rasio-rasio keuangan perusahaan, diantaranya ROA (return on asset), DER (debt to equity ratio), dan DPR (dividend payout ratio). Fluktuasi nilai perusahaan mengindikasikan bahwa perusahaan akan terus berusaha agar memaksimalkan nilai perusahaannya. Salah satu cara untuk memaksimalkan nilai perusahaan tersebut adalah dengan menciptakan keselarasan tujuan maupun kepentingan antara manajer dan para pemegang saham atau prinsipal. Pihak prinsipal memberikan tugas dan wewenang kepada manajemen untuk mengelola perusahaan. Perusahaan yang menyampaikan informasi lebih lanjut mengenai aktivitas mereka akan lebih mampu menarik investasi karena hal tersebut akan menarik kepercayaan investor (Birjandi et al., 2015).Naik turunnya nilai suatu perusahaan ini dapat juga dipengaruhi beberapa faktor yang ada di dalam perusahaan, seperti kebijakan-kebijakan yang dilakukan perusahaan. Keberhasilan perusahaan untuk mencapai tujuannya dari waktu ke waktu akan menentukan bagaimana bisnis dan arah kebijakan perusahaan(Andawasatya et al., 2017).

Nilai perusahaan dapat ditentukan melalui profitabilitas perusahaan. Profitabilitas merupakan kemampuan perusahaan memperoleh laba dalam hubungannya dengan penjualan, total aktiva maupun modal sendiri (Sartono, 2010:121).Salah satu indikator penting bagi investor dalam menilai prospek perusahaan di masa depan adalahdengan melihat pertumbuhan profitabilitas 
dari tahun-tahun sebelumnya apakah mengalami peningkatan atau justru mengalami penurunan.Peningkatan profitabilitas dari tahun sebelumnya mengindikasikan bahwa prospek perusahaan bagus sehingga investor akan merespon positif dan nilai perusahaan akan meningkat. Apabila profitabilitas mengalami penurunan dari tahun sebelumnya, maka hal tersebut dapat memunculkan respon negatif dan nilai perusahaan akan menurun. Profitabilitas juga menentukan seberapa besar return yang akan diterima oleh investor atas investasi yang dilakukannya (Herawati, 2013).

Besarnya nilai perusahaan dipengaruhi kebijakan yang akan diambil oleh perusahaan. Salah satu kebijakan yang memengaruhinya adalah kebijakan utang. Kebijakan utang merupakan kebijakan pendanaan yang bersumber dari pihak eksternal perusahaan (Hasnawati, 2005). Penggunaan utang sebagai pembiayaan kegiatan perusahaan dapat memberikan keuntungan yang berasal dari pengurangan pajak karena adannya bunga yang dibayarkan akibat utang akan mengurangi penghasilan yang terkena pajak. Selain itu, penggunaan utang mampu menarik pemegang saham untuk melakukan kontrol yang lebih ketat dibandingkan perusahaan memperoleh pendanaan melalui penerbitan saham baru (Rahmawati, 2012). Selain keuntungan yang diperoleh dari penggunaan utang terdapat pula risiko didalam penggunaan utang sebagai sumber pendanaan, antara lain terdapat risiko gagal bayar yang terkandung didalamnya dan beban yang ditanggung oleh perusahaan akan bertambah dengan adannya beban bunga. Keuntungan pajak yang diperoleh lebih kecil dibandingkan dengan beban bunga yang harus dibayarkan.

Penambahan utangmampu memberikan sinyal positif, karena investor menganggap itu sebagai kemampuan perusahaan membayar kewajibannya di masa depan. Menurut Ellili(2011), walaupun mampu meningkatkan risiko kebangkrutan perusahaan, peningkatan utang adalah sinyal positif di pasar yang menunjukkan kekuatan manajer untuk menghasilkan keuntungan yang cukup dalam membayar bunga maupun kewajibannya. Penambahan utang juga mampu memberikan manfaat pajak untuk perusahaan, karena biaya bunga atas utang dapat digunakan sebagai pengurang dari penghasilan kena pajak perusahaan.Komposisi utang yang terlalu tinggi dapat meningkatkan risiko, yaitu ketidakmampuan perusahaan untuk membayar utang-utangnya, tingginyarisiko dikarenakan bunga akan meningkat lebih tinggi daripada penghematan pajak (Sofyaningsih dan Hardiningsih, 2011).

Pada trade off theory, perusahaan akan berutang sampai pada tingkat utang tertentu, dimana penghematan pajak (tax shields) dari tambahan utang sama dengan biaya kesulitan keuangan (financial distress)(Myers, 2001).Trade off theory dalam menentukan struktur modal yang optimal memasukkan beberapa faktor antara lain pajak, biaya keagenan (agency costs) dan biaya kesulitan keuangan (financial distress) tetapi tetap mempertahankan asumsi efisiensi pasar dan symmetric information sebagai imbangan dan manfaat penggunaan utang(Jensen dan Meckling, 1976).Pendanaan yang dilakukan melalui utang yang terlalu tinggi dapat membuat nilai perusahaan turun, maka manajemen harus mengambil keputusan tepatuntuk menentukan kebijakan utang perusahaan karena akan memengaruhi tinggi rendahnya nilai perusahaan. 
Nilai perusahaan dapat dilihat dari kemampuan perusahaan membayar dividen. Pendistribusian laba berupa dividen atau penahanan laba untuk pendanaan proyek di masa depan disebut kebijakan dividen. Kebijakan dividen adalah suatu keputusan guna menentukan apakah laba yang diperoleh perusahaan akan dibagikan kepada investor sebagai dividen atau akan ditahan dalam bentuk laba ditahan guna pembiayaan investasi di masa mendatang. Apabila perusahaan memilih untuk membagikan dividen maka tingkat pertumbuhan akan berkurang sehingga berdampak negatif terhadap saham perusahaan. Apabila perusahaan tidak membagikan dividen maka pasar akan memberikan sinyal negatif terhadap prospek perusahaan sehingga peningkatan dividen memberikan sinyal perubahan yang menguntungkan pada harapan manajer dan penurunan dividen menunjukkan sinyal negatif pada prospek perusahaan di masa yang akan datang (Aharony and Swary, 1980).

Kebijakan dividen tetap menjadi salah satu kebijakan keuangan terpenting untuk sebuah perusahaan. Kebijakan dividen membawa informasi tentang prospek perusahaan untuk pertumbuhan laba di masa depan dan informasi tersebut dapat mengundang respondari investor sehingga akan memengaruhi nilai perusahaan (Chandra et al., 2017). Para investor memiliki tujuan utama untuk meningkatkan kesejahteraandengan mengharapkan pengembalian dalam bentuk dividen maupun capital gain. Seorang investor yang tidak bersedia berspekulasi akan lebih memilih dividen daripada capital gain.

Besarnya dividen ini dapat memengaruhi harga saham. Apabila dividen yang dibayar tinggi, maka harga saham cenderung tinggi sehingga nilai perusahaan juga tinggi. Sebaliknya jika dividen yang dibayarkan kecil maka harga saham perusahaan tersebut juga rendah. Kemampuan membayar dividen erat hubungannya dengan kemampuan perusaphaan memperoleh laba. Jika perusahaan memperoleh laba yang besar, maka kemampuan membayar dividen juga besar. Oleh karena itu, dividen yang besar akan meningkatkan nilai perusahaan (Nurfauziah dkk., 2016).

Penelitian mengenai hubungan profitabilitas dengan nilai perusahaan oleh Pratama dan Wirawati(2016) menemukan hasil bahwa profitabilitas berpengaruh positif terhadap nilai perusahaan. Arah positif tersebut memiliki arti bahwa semakin meningkat profitabilitas maka nilai perusahaan yang diperoleh juga meningkat.Hasil penelitian tersebut selaras dengan hasil penelitian yang dilakukan Dewi dan Wirajaya (2013), Rosi (2012), serta Indasari dan Yadnyana(2018), berbeda dengan penelitian yang dilakukan oleh Ustiani(2013) menemukan hasil bahwa profitabilitas tidak memiliki pengaruh terhadap nilai perusahaan. Hasil penelitian tersebut selaras dengan hasil penelitian yang dilakukan Pratiwi dan Mertha(2017).

Penelitian mengenai hubungan kebijakan utang dengan nilai perusahaan belum menunjukkan hasil yang konsisten diantara peneliti. Penelitian yang dilakukan oleh Sari dan Wirajaya(2017) menemukan bahwa kebijakan utang berpengaruh positif terhadap nilai perusahaan. Temuan ini selaras dengan penelitian yang dilakukan oleh Sadia dan Sujana(2017), serta Pratiwi dan Mertha(2017). Penelitian tersebut bertentangan dengan hasil penelitian yang dilakukan oleh Cortez dan Stevie (2012) dan Nasehah dan Widyarti(2012)yang menyatakan bahwa kebijakan utang berpengaruh negatif terhadap nilai 
perusahaan. Penelitian yang dilakukan oleh Sofyaningsih dan Hardiningsih(2011) serta Mahendra, dkk.(2012) menemukan bahwa tidak adanya pengaruh antara kebijakan utang dengan nilai perusahaan.

Penelitian mengenai hubungan kebijakan dividen dengan nilai perusahaan belum menunjukkan hasil yang konsisten diantara peneliti. Penelitian yang dilakukan oleh (Octaviani dan Astika, 2016)menemukan bahwa kebijakan dividen berpengaruh positif terhadap nilai perusahaan, selaras dengan penelitian Suartawan dan Yasa (2016), serta Dewi dan Wirasedana(2018). Di sisi lain, Dewi dan Putri(2017)menemukan bahwa kebijakan dividen berpengaruh negatif terhadap nilai perusahaan.

Profitabilitas adalah kemampuan perusahaan dalam memperoleh laba. Laba merupakan tingkat keuntungan bersih yang mampu diraih oleh perusahan pada saat menjalankan operasinya. Laba yang layak dibagikan kepada pemegang saham adalah laba setelah bunga dan pajak.Peningkatan jumlah laba yang dihasilkan dari tahun sebelumnya menunjukkan bahwa prospek perusahaan untuk menjalankan operasinya di masa depan juga tinggi, sehingga nilai perusahaan yang tercermin dari harga saham akan ikut meningkat. Hal ini sesuai dengan signalling theory yang menyatakan bahwa perusahaan yang memiliki laba yang tinggi, merupakan sinyal bahwa perusahaan tersebut mempunyai prospek bagus di masa yang akan datang (Sujoko and Soebiantaro, 2007).

Penelitian mengenai hubungan profitabilitas dengan nilai perusahaan oleh Pratama dan Wirawati(2016) menemukan hasil bahwa profitabilitas berpengaruh positif terhadap nilai perusahaan. Arah positif tersebut memiliki arti bahwa semakin meningkat profitabilitas maka nilai perusahaan yang diperoleh juga meningkat.Hasil penelitian tersebut selaras dengan hasil penelitian yang dilakukan Dewi dan Wirajaya (2013), serta Indasari dan Yadnyana(2018).Berdasarkan kajian teoritis, kajian empiris dan dasar logika, maka hipotesis alternatif yang diajukan dalam penelitian ini adalah sebagai berikut.

$\mathrm{H}_{1}$ : Profitabilitas berpengaruh positif terhadap nilai perusahaan.

Kebijakan perusahaan dalam menentukan seberapa jauh perusahaan menggunakan pendanaan utang haruslah berhati-hati, karena keputusantersebutsangat sensitif terhadap perubahan nilai perusahaan. Teori trade off menjelaskan bahwa struktur modal optimal suatu perusahaan ditentukan dengan mempertimbangkan manfaat pengurangan pajak ketika utang meningkat. Penggunaan utang dapat meningkatkan nilai perusahaan karena biaya bunga utang adalah biaya yang mengurangi pembayaran pajak. Meskipun dapat meningkatkan risiko kebangkrutan perusahaan, peningkatan utang merupakan sinyal positif di pasar yang menunjukkan kekuatan manajer dalam menghasilkan keuntungan yang cukup untuk membayar bunga maupun kewajibannya (Ellili, 2011).

Penelitian yang dilakukan oleh Sari dan Wirajaya(2017) menemukan bahwa kebijakan utang berpengaruh positif terhadap nilai perusahaan. Temuan ini selaras dengan penelitian yang dilakukan oleh Sadia dan Sujana (2017), serta Pratiwi dan Mertha(2017). Berdasarkan kajian teoritis, kajian empiris dan dasar 
logika, maka hipotesis alternatif yang diajukan dalam penelitian ini adalah sebagai berikut.

$\mathrm{H}_{2}$ : Kebijakan utang berpengaruh positif terhadap nilai perusahaan.

Inti dari teori sinyal adalah bahwa manajemen perusahaan cenderung memiliki pengetahuan pribadi tentang situasi saat ini dan masa depan perusahaan mereka daripada yang dimiliki orang luar(Budagaga, 2017). Bhattacharya(1979) mengemukakan bahwa pembayaran dividen dapat berfungsi sebagai sinyal kesehatan keuangan perusahaan, dengan peningkatan dividen yang mengindikasikan bahwa manajer mengharapkan bisnis mereka memiliki arus kas yang lebih tinggi di masa depan. Sebagai akibatnya, nilai yang lebih tinggi ditandai oleh dividen yang lebih tinggi.Fama dan French(1998) menemukan bahwa investasi yang dihasilkan dari kebijakan dividen memiliki informasi yang positif tentang perusahaan di masa yang akan datang, selanjutnya berdampak positif terhadap nilai perusahaan.

Penelitian yang dilakukan oleh (Octaviani dan Astika, 2016)menemukan bahwa kebijakan dividen berpengaruh positif terhadap nilai perusahaan, selaras dengan penelitian Suartawan dan Yasa(2016),serta Reni dan Pratiwi(2015). Berdasarkan kajian teoritis, kajian empiris dan dasar logika, maka hipotesis alternatif yang diajukan dalam penelitian ini adalah sebagai berikut.

$\mathrm{H}_{3}$ : Kebijakan dividen berpengaruh positif terhadap nilai perusahaan.

\section{METODE PENELITIAN}

Lokasi penelitian ini dilakukan pada perusahaan sektor pertambangan yang terdaftar di Bursa Efek Indonesia yang dimana data tersebut diperoleh dari laporan keuangan perusahaan sektor pertambangan tahun 2014-2017 melalui alamat website $w w w . i d x . c o . i d ~(d i a k s e s$ pada tanggal 30 November 2018). Sektor pertambangan memiliki kontribusi besar terhadap berbagai aspek mulai dari Penanaman Modal Asing (PMA), Penanaman Modal Dalam Negeri (PMDN), kegiatan ekspor, penerimaan devisa,pendapatan negara dan produk domestik bruto. Sektor pertambangan juga mampu membuka lapangan pekerjaan dan menyerap tenaga kerja yang nantinyamengurangi pengangguran dan membutuhkan dana besar sehingga untuk memenuhi dana tersebut perusahaan akan membutuhkan dana dari investor, maka dari itu penulis tertarik untuk meneliti perusahaan sektor pertambangan dengan harapan dapat memberikan informasi yang lebih baik bagi penulis dan calon investor yang ingin berinvestasi dalam saham.

Tobin's Q mewakili sejumlah variabel yang penting dalam pengukuran kinerja, antara lain aktiva tercatat perusahaan, kecenderungan pasar yang memadai seperti pandangan-pandangan analis mengenai prospek perusahaan, dan variabel modal intelektual atau intangible asset. Rumus Tobin's Q dapat diformulasikan sebagai berikut (Chung dan Pruitt, 1994):

$Q=\frac{M V E+D E B T}{T A}$

Keterangan:

$\mathrm{Q} \quad=$ Nilai perusahaan

MVE = Nilai pasar ekuitas (jumlah saham beredar $\times$ closing price)

DEBT $=$ Liabilitas 
TA $=$ Nilai buku total aset

Return on Asset (ROA) dihitung berdasarkan perbandingan laba bersih setelah pajak terhadap total aktiva yang dimiliki perusahaan dirumuskan sebagai berikut(Marlina dan Danica 2009):

Return On Asset $=\frac{\text { Laba bersih setelah pajak }}{\text { Total Aktiva }} \times 100 \%$

Kebijakan utang diukur dengan debt to equity ratio (DER)yang menunjukkan perbandingan antara pembiayaan dan pendanaan melalui utang dengan pendanaan melalui ekuitas dengan rumus sebagai berikut (Oladipupo dan Okafor, 2013):

Dept to Equity Ratio $=\frac{\text { Total Utang }}{\text { Total Ekuitas }}$

Kebijakan dividen dapat diproksikan dengan DPR (Dividend Payout Ratio) yang dihitung dengan rumus sebagai berikut (Mardasari, 2014):

Dividend Payout Ratio $=\frac{\text { Dividen per lembar saham }}{\text { Laba per lembar saham }} \times 100 \%$

Populasi dalam penelitian ini adalah 47 perusahaan-perusahaan sektor pertambangan yang terdaftar di Bursa Efek Indonesia tahun 2014-2017.Metode yang digunakan purposive sampling. Setelah sampel diseleksi, maka didapatkan jumlah sampel sebanyak 14 perusahaan, ditambahkan dengan empat tahun penelitian menjadi 56 pengamatan.Dalam penelitian ini ditemukan sebanyak 12 data outlier sehingga jumlah pengamatan menjadi 44 pengamatan.

Analisis regresi linear berganda dimaksudkan untuk menguji pengaruh simultan dari beberapa variabel bebas terhadap satu variabel terikat. Analisis regresi dapat memberikan jawaban mengenai besarnya pengaruh setiap variabel independen terhadap variabel dependennya. Dalam penelitian ini model regresi linear berganda yang akan dikembangkan adalah sebagai berikut:

$Y=\alpha+\beta_{1} . X_{1}+\beta_{2} . X_{2}+\beta_{3} . X_{3}+e$

Keterangan :

\begin{tabular}{|c|c|}
\hline Y & = Nilai Perusahaan \\
\hline a & = Nilai Konstanta \\
\hline$\beta_{1}, \beta_{2}, \beta_{3}$ & $=$ Koefisien Regresi Variabel Independen \\
\hline $\mathrm{X}_{1}$ & $=$ Profitabilitas \\
\hline$X_{2}$ & = Kebijakan Utang \\
\hline$X_{3}$ & = Kebijakan Dividen \\
\hline & $=$ standard error \\
\hline
\end{tabular}

\section{HASIL DAN PEMBAHASAN}

Berdasarkan Tabel 2 pada variabel nilai perusahaan yang diproksikan dengan Tobin's Q menunjukkan nilai minimum sebesar 0,445pada perusahaan Harum Energytahun 2015 memiliki arti bahwa pasar menghargai saham perusahaan di bawah harga sebenarnya. Nilai maksimum sebesar 2,577 pada perusahaan Bayan Resources tahun 2016 memiliki arti bahwa pasar menghargai saham perusahaan di atas harga sebenarnya. Nilai rata-rata sebesar 1,20202dengan standar deviasi 0,456861, menunjukkan bahwa tidak adanya ketimpangan yang besar nilai Tobin's $Q$ dari 14 perusahaan selama empat tahun pengamatan. 
Statistik deskriptif disajikan untuk memberikan informasi mengenai karakteristik variabel-variabel penelitian, yaitu jumlah sampel, nilai minimum, nilai maksimum, nilai rata-rata, dan standar deviasi. Hasil statistik deskriptif penelitian ini dapat dilihat pada Tabel 2.

\section{Tabel 2. Hasil Statistik Deskriptif}

\begin{tabular}{llrrcr}
\hline & N & Minimum & Maximum & Mean & Std. Deviation \\
\hline Nilai Perusahaan & 44 & 0,445 & 2,577 & 1,20202 & 0,456861 \\
Profitabilitas & 44 & $-0,050$ & 0,318 & 0,09275 & 0,069980 \\
Kebijakan Utang & 44 & 0,108 & 3,070 & 0,87391 & 0,721767 \\
Kebijakan Dividen & 44 & $-0,163$ & 0,788 & 0,29827 & 0,221816 \\
Valid N (listwise) & 44 & & & & \\
\hline
\end{tabular}

Sumber: Data Penelitian, 2018

Berdasarkan Tabel 2 pada variabel Profitabilitas yang diproksikan dengan ROA menunjukkan nilai minimum sebesar -0,050 pada perusahaan Harum Energy tahun 2015, memiliki arti bahwa kemampuan perusahaan dalam menghasilkan laba menurun sebesar lima persen. Nilai maksimum sebesar 0,318 pada perusahaan Mitrabara Adiperdana tahun 2015, memiliki arti bahwa kemampuan perusahaan dalam menghasilkan laba meningkat sebesar 31,8 persen. Nilai rata-rata sebesar 0,09275 dengan standar deviasi 0,069980, menunjukkan bahwa tidak adanya ketimpangan yang besar nilai ROA dari 14 perusahaan selama empat tahun pengamatan.

Berdasarkan Tabel 2 pada variabel kebijakan utang yang diproksikan dengan DER menunjukkan nilai minimum sebesar 0,108 pada perusahaan Harum Energy tahun 2015, memiliki arti bahwa rasio utang perusahaan lebihkecil dari ekuitas yang dimilikinya. Nilai maksimum sebesar 3,070 pada perusahaan Radiant Utama Interinsco tahun 2014, memiliki arti bahwa rasio utang perusahaan lebih besar dari ekuitas yang dimilikinya. Nilai rata-rata sebesar 0,87391 dengan standar deviasi 0,721767, menunjukkan bahwa tidak adanya ketimpangan yang besar nilai DER dari 14 perusahaan selama empat tahun pengamatan.

Berdasarkan Tabel 2 pada variabel kebijakan dividen yang diproksikan dengan DPR menunjukkan nilai minimum sebesar -0,163 pada perusahaan Harum Energy tahun 2015, memiliki arti bahwa 16,3 persen tambahan ekuitas yang diterima oleh pemegang saham dari total kerugian perusahaan. Nilai maksimum sebesar 0,788 pada perusahaan Indo Tambangraya Megah tahun 2017, memiliki arti bahwa 78,8 persen tambahan ekuitas yang diterima oleh pemegang saham dari total keuntungan perusahaan. Nilai rata-rata sebesar 0,29827 dengan standar deviasi 0,221816, menunjukkan bahwa tidak adanya ketimpangan yang besar nilai DER dari 14 perusahaan selama empat tahun pengamatan.

Analisis regresi linear berganda dimaksudkan untuk menguji pengaruh simultan dari beberapa variabel bebas terhadap satu variabel terikat. Analisis regresi dapat memberikan jawaban mengenai besarnya pengaruh setiap variabel independen terhadap variabel dependennya. Penelitian ini menggunakan model persamaan regresi berganda untuk mengetahui hubungan antara profitabilitas, kebijakan utang, dan kebijakan dividen pada nilai perusahaan sektor 
pertambangan yang terdaftar di Bursa Efek Indonesia. Hasil analisis regresi linear berganda disajikan pada Tabel 3 .

Tabel 3. Hasil Uji Regresi Linear Berganda

\begin{tabular}{lrrrrr}
\hline & \multicolumn{2}{c}{$\begin{array}{c}\text { Unstandardized } \\
\text { Coefficients }\end{array}$} & $\begin{array}{c}\text { Standardized } \\
\text { Coefficients }\end{array}$ & & \\
\cline { 2 - 4 } & \multicolumn{1}{c}{ B } & Std. Error & Beta & \multicolumn{1}{c}{ T } & \multicolumn{1}{c}{ Sig. } \\
\hline (Constant) & 0,744 & 0,161 & & 4,612 & 0,000 \\
Profitabilitas & 3,084 & 0,877 & 0,472 & 3,518 & 0,001 \\
Kebijakan Utang & $-0,004$ & 0,086 & $-0,007$ & $-0,050$ & 0,960 \\
Kebijakan Dividen & 0,590 & 0,270 & 0,287 & 2,184 & 0,035 \\
\hline
\end{tabular}

Sumber: Data Penelitian, 2018

Berdasarkan hasil analisis regresi linear berganda pada Tabel 3, maka persamaan regresi yang digunakan dalam penelitian ini dapat ditulis sebagai berikut:

Keterangan :

$$
Y=0,744+3,084 X_{1}-0,004 X_{2}+0,590 X_{3}
$$

$\mathrm{Y}=$ Nilai Perusahaan

$\mathrm{X}_{1} \quad=$ Profitabilitas

$\mathrm{X}_{2} \quad=$ Kebijakan Utang

$\mathrm{X}_{3} \quad=$ Kebijakan Dividen

$e \quad=$ standard error

Nilai konstanta sebesar 0,744 artinya jika nilai variabel profitabilitas, kebijakan utang, dan kebijakan dividen dianggap konstan (tetap atau tidak ada perubahan) menyebabkan nilai variabel nilai perusahaan sebesar 0,744.Nilai koefisien variabel profitabilitas sebesar 3,084 artinya jika nilai variabel profitabilitas mengalami kenaikan satu persen, maka variabel nilai perusahaan mengalami kenaikan sebesar 308,4 persen dengan asumsi variabel independen lain konstan.Nilai koefisien variabel kebijakan utang sebesar -0,004 artinya jika nilai variabel kebijakan utang mengalami kenaikan satu persen, maka variabel nilai perusahaan mengalami penurunan sebesar 0,4 persen dengan asumsi variabel independen lain konstan.

Nilai koefisien variabel kebijakan dividen sebesar 0,590 artinya jika nilai variabel kebijakan dividen mengalami kenaikan satu persen, maka variabel nilai perusahaan mengalami kenaikan sebesar 59 persen dengan asumsi variabel independen lain konstan.Uji F dilakukan untuk mengetahui kelayakan model regresi linear berganda sebagai alat analisa yang menguji pengaruh variabel bebas terhadap variabel terikat.Uji $\mathrm{F}$ dapat dilakukan hanya dengan melihat nilai signifikansi $\mathrm{F}$ yang terdapat pada output hasil analisis regresi menggunakan SPSS. Jika angka signifikansi $F$ lebih kecil dari a $(0,05)$, maka model regresi dikatakan layak atau variabel bebas mampu menjelaskan variabel terikat. Hasil uji F disajikan pada Tabel 4.

Tabel 4. Hasil Uji Kelayakan Model

\begin{tabular}{llrrrrc}
\hline \multicolumn{2}{l}{ Model } & Sum of Squares & \multicolumn{1}{c}{$d f$} & Mean Square & F & \multicolumn{1}{c}{ Sig. } \\
\hline 1 & Regression & 3,246 & 3 & 1,082 & 7,555 &, $000(\mathrm{a})$ \\
& Residual & 5,729 & 40 & 0,143 & & \\
& Total & 8,975 & 43 & & & \\
\hline
\end{tabular}

Sumber: Data Penelitian, 2018 
Berdasarkan Tabel 4 dapat dilihat bahwa nilai $F$ sebesar $7,555>\mathrm{df}(3 ; 44)=2,82$ dengan probabilitas sebesar $0,000<\mathrm{a}=0,05$. Hal ini berarti seluruh independen (profitabilitas, kebijakan utang, dan kebijakan dividen) dapat memprediksi atau dapat menjelaskan fenomena nilai perusahaan pada perusahaan sektor pertambangan yang terdaftar di BEI periode 2014-2017, sehingga model ini layak untuk diujikan dan pembuktian hipotesis dapat dilakukan.

Uji koefisien determinasi $\left(\mathrm{R}^{2}\right)$ digunakan untuk menguji goodness-fit dari model regresi. Nilai adjusted $R^{2}$ besarnya dari nol sampai satu. Apabila nilai adjusted $\mathrm{R}^{2}=0$ maka variabel bebas tidak berpengaruh pada variabel terikat. Sedangkan nilai adjusted $\mathrm{R}^{2}$ mendekati 1 maka variabel bebas berpengaruh sempurna pada variabel terikat.

Berdasarkan data regresi penelitian ini memiliki nilai Adjusted $R$ Square sebesar 0,314 yang berarti bahwa 31,4 persen variasi nilai perusahaan yang diukur dengan Tobin's $Q$ dapat dijelaskan oleh ketiga variabel independen yang terdiri dari profitabilitas, kebijakan utang, dan kebijakan dividen sedangkan sisanya sebesar 68,6 persen dipengaruhi oleh variabel lain yang tidak dimasukkan dalam model penelitian.

Uji $t$ merupakan pengujian yang dilakukan untuk mengetahui pengaruh variabel independen dalam penelitian terhadap variabel dependen. Apabila nilai signifikansi lebih kecil dari 0,05, maka dapat disimpulkan bahwa variabel independen secara parsial berpengaruh signifikan terhadap variabel dependen. Hasil uji t untuk masing-masing variabel independen disajikan dalam Tabel 5.

Tabel 5. Hasil Uji Hipotesis

\begin{tabular}{|c|c|c|c|c|c|}
\hline & \multicolumn{2}{|c|}{$\begin{array}{l}\text { Unstandardized } \\
\text { Coefficients }\end{array}$} & \multirow{2}{*}{$\begin{array}{c}\text { Standardized } \\
\text { Coefficients }\end{array}$} & \multirow[b]{2}{*}{$t$} & \multirow[b]{2}{*}{ Sig. } \\
\hline & $B$ & Std. Error & & & \\
\hline (Constant) & 0,744 & 0,161 & & 4,612 & 0,000 \\
\hline Profitabilitas & 3,084 & 0,877 & 0,472 & 3,518 & 0,001 \\
\hline Kebijakan & & & & & \\
\hline $\begin{array}{l}\text { Utang } \\
\text { Kebijakan }\end{array}$ & $-0,004$ & 0,086 & $-0,007$ & $-0,050$ & 0,960 \\
\hline Dividen & 0,590 & 0,270 & 0,287 & 2,184 & 0,035 \\
\hline
\end{tabular}

Sumber: Data Penelitian, 2018

Hipotesis pertama dalam penelitian ini adalah profitabilitas berpengaruh positif pada nilai perusahaan. Berdasarkan Tabel 6, hasil uji $t$ variabel profitabilitas dengan signifikansi 0,001 lebih kecil dari $\alpha=0,05$. Variabel profitabilitas memiliki nilai koefisien positif sebesar 3,084 dengan probabilitas signifikan sebesar $0,001<0,05$, maka variabel profitabilitas berpengaruh positif pada nilai perusahaan, sehingga hipotesis pertama $\left(\mathrm{H}_{1}\right)$ diterima.

Hipotesis kedua dalam penelitian ini adalah kebijakan utang berpengaruh positif pada nilai perusahaan. Berdasarkan Tabel 6, hasil uji t variabel kebijakan utang dengan signifikansi 0,960 lebih besar dari $\alpha=0,05$. Variabel kebijakan utang memiliki nilai koefisien negatif sebesar 0,004 dengan probabilitas signifikan sebesar 0,960>0,05, maka variabel kebijakan utang tidak berpengaruh pada nilai perusahaan, sehingga hipotesis kedua $\left(\mathrm{H}_{2}\right)$ ditolak. 
Hipotesis ketiga dalam penelitian ini adalah kebijakan dividen berpengaruh positif pada nilai perusahaan. Berdasarkan Tabel 6 , hasil uji $t$ variabel kebijakan dividen dengan signifikansi 0,035 lebih kecil dari $a=0,05$. Variabel kebijakan dividen memiliki nilai koefisien positif sebesar 0,590 dengan probabilitas signifikan sebesar $0,035<0,05$, maka variabel kebijakan dividen berpengaruh positif pada nilai perusahaan, sehingga hipotesis ketiga $\left(\mathrm{H}_{3}\right)$ diterima.

Berdasarkan hasil analisis regresi berganda, variabel profitabilitas memiliki nilai koefisien positif sebesar 3,084 dengan tingkat signifikansi sebesar 0,001 yang lebih kecil dari 0,05 . Hal ini berarti variabel profitabilitas berpengaruh positif terhadap nilai perusahaan, sehingga hipotesis pertama $\left(\mathrm{H}_{1}\right)$ diterima. Hasil penelitian ini sejalan dengan hasil penelitian yang dikemukakan oleh Dewi dan Wirajaya(2013), Pratama dan Wirawati(2016), serta Indasari dan Yadnyana(2018) yang menyatakan bahwa profitabilitas berpengaruh positif terhadap nilai perusahaan.Arah positif tersebut memiliki arti bahwa semakin meningkat profitabilitas yang diproksikan dengan ROA (Return on Asset) maka nilai perusahaan yang diperoleh juga akan meningkat.Teori sinyal menjelaskan bagaimanaperusahaan mengeluarkan sinyal berupa informasi yang dapat menjelaskan keadaanperusahaan tersebut. Sinyal yangdikeluarkan oleh perusahaan tersebut dapat membantu investor dalam memperkirakan kondisi suatuperusahaan dimasa yang akan datang. Informasi yang dikeluarkan oleh perusahaan dapat berupa informasi keuangan yang mampu menjelaskan kinerja keuangan perusahaan tersebut dandapat diukur dengan menghitung komponenkomponen dari laporan keuangan tersebut menjadi rasio keuangan.

Salah satu rasio keuanganyang digunakan adalah Return on Asset (ROA). ROA menunjukkan kemampuanperusahaan menghasilkan laba dengan menggunakan seluruh aktiva yang dimilikiperusahaan. Dengan mengetahui ROA sebuah perusahaan, kita dapat menilainya apakah perusahaan sudah efektif dalam memakai aktivanya dalam aktivitas operasi untuk membuahkan keuntungan.Dengan kata lain, makin tinggi rasio ini jadi makin baik produktivitas aset dalam memperoleh keuntungan bersih. Profitabilitas yang tinggi menunjukkan prospek perusahaan yang bagus sehinggga memicu permintaan saham oleh investor. Respon positif dari investor tersebut akan meningkatkan harga saham dan selanjutnya akan meningkatkan nilai perusahaan (Hermuningsih, 2013).

Berdasarkan hasil analisis regresi berganda, variabel kebijakan utang memiliki nilai koefisien negatif sebesar 0,004 dengan tingkat signifikansi sebesar 0,960 yang lebih besar dari 0,05 . Hal ini berarti variabel kebijakan utang tidak berpengaruh terhadap nilai perusahaan, sehingga hipotesis kedua $\left(\mathrm{H}_{2}\right)$ ditolak karena dilihat dari data hasil statistik deskriptif pada penelitian ini menunjukkan rata-rata variabel nilai perusahaan sebesar 1,20202dengan standar deviasi sebesar 0,456861 yang berarti bahwa tidak adanya ketimpangan yang besar pada nilai Tobin's Q dari 14 perusahaan sektor pertambangan selama empat tahun pengamatan. Data tersebut juga menunjukkan bahwa tidak adanya perubahan yang signifikan pada nilai perusahaan yang disebabkan oleh besar kecilnya rasio penggunaan utang yang digunakan. Maka, besar kecilnya penggunaan utang 
sebagai sumber dana dari perusahaan sektor pertambangan tidak memiliki pengaruh pada nilai perusahaan.

Dilihat dari data perusahaan Bukit Asam (PTBA) tahun 2014 memiliki nilai Tobin's Q sebesar 2,36 dengan DER sebesar 0,71, namun tahun 2015 nilai Tobin's $Q$ turun menjadi 1,07 dengan DER yang naik menjadi 0,82 , selanjutnya tahun 2016 nilai Tobin's Q naik menjadi 1,98 tetapi DER turun menjadi 0,76, namun pada tahun 2017 nilai Tobin's Q turun menjadi 1,66 dan DER juga turun menjadi 0,59, maka terdapat ketidakpastian pengaruh DER terhadap Tobin's Q. Tidak adanya pengaruh kebijakan utang dengan nilai perusahaan mengindikasikan bahwa biaya utang maupun biaya ekuitas adalah relatif ekuivalen dan masingmasing memiliki keunggulan dan kelemahan(Sofyaningsih dan Hardiningsih, 2011).

Hal ini juga didukung dengan penelitian yang dilakukan oleh Sumanti dan Mangantar(2015) yang menyatakan kebijakanutang tidak berpengaruh terhadap nilai perusahaan, penggunaan modal utang akan menguntungkan apabila iklim bisnis baik sehingga manfaat dari penggunaan utang akan lebih besar dibandingkan dengan biaya bunga utangnya, sedangkan pada perusahaan sektor pertambangan sering terjadi fluktuasi pada harga komoditinya, sehingga iklim bisnis pada perusahaan sektor pertambangan tidak menentu yang menimbulkan manfaat dari penggunaan utang dapat lebih kecil dari biaya bunga utang yang ditimbulkan. Hasilini sejalan dengan hasil penelitian yang dikemukakan oleh Sofyaningsih dan Hardiningsih(2011) dan Pertiwi, dkk. (2016) yang menyatakan bahwa kebijakan utangtidak berpengaruh terhadap nilai perusahaan.

Berdasarkan hasil analisis regresi berganda, variabel kebijakan dividen memiliki nilai koefisien positif sebesar 0,590 dengan tingkat signifikansi sebesar 0,035 yang lebih kecil dari 0,05 . Hal ini berarti variabel kebijakan dividen berpengaruh positif terhadap nilai perusahaan, sehingga hipotesis ketiga $\left(\mathrm{H}_{3}\right)$ diterima. Hasil penelitian ini sejalan dengan hasil penelitian yang dikemukakan oleh (Octaviani dan Astika, 2016), Suartawan dan Yasa (2016), serta Dewi dan Wirasedana (2018) yang menyatakan bahwa kebijakan dividen berpengaruh positif terhadap nilai perusahaan.

Hasil analisis membuktikan bahwa kebijakan dividen berpengaruh positif pada nilai perusahaan dan hal ini mengindikasikan bahwa semakin tinggi angka dividend payout ratio, semakin tinggi pula nilai perusahaan yang di proksi oleh Tobin's Q. Pembayaran dividen penting bagi investor karena dividen memberikan kepastian tentang perkembangan keuangan perusahaan. Dividen sangat menarikbagi investor karena dapat mengamankan penghasilan saat ini(Dewi dan Wirasedana, 2018).

Hasil penelitian inisesuai dengan teori sinyal dimana pembayaran dividen dilakukan pihakmanajemen untuk memberikan sinyal mengenai keberhasilan perusahaan dalam menghasilkan keuntungan.Miller and Modigliani(1961)mendasari bahwa pemberian informasi mengenai tingkat pembayaran dividen tunai akan memiliki kandungan informasi yang berpengaruh pada reaksi harga saham. Bhattacharya(1979) mengemukakan bahwa pembayaran dividen dapat berfungsi sebagai sinyal kesehatan keuangan perusahaan, dengan peningkatan dividen yang mengindikasikan bahwa manajer mengharapkan bisnis mereka memiliki arus kas yang lebih tinggi di masa depan. 
Sebagai akibatnya, nilai yang lebih tinggi ditandai oleh dividen yang lebih tinggi.Pernyataan ini juga didukung dengan adanya teorimengenai kebijakan dividen yaitu bird in the hand theory. Teori ini berargumenbahwa investor menilai dividen lebih baik daripada capital gain sifatnya yanglebih pasti(Gordon dan Lintner, 1956). Sehingga apabila perusahaan meningkatkan pembayaran dividen makanilai perusahaan juga akan meningkat.

Implikasi teoritis dari penelitian ini adalah bagaimana signalling theory, trade off theory, bird in hand theory, dan dividend signalling theory menjelaskan pengaruh profitabilitas, kebijakan utang, dan kebijakan dividen secara langsung pada nilai perusahaan. Hasil penelitian ini memberikan wawasan terkait nilai perusahaan, profitabilitas, kebijakan utang, dan kebijakan dividen. Penelitian ini juga mendukung teori sinyal, yaitu suatu tindakan yang diambil oleh manajemen perusahaan yang memberikan petunjuk berupa informasi bagi investor tentang bagaimana manajemen memandang prospek perusahaan. Apabila profitabilitas yang tinggi menunjukkan prospek perusahaan yang bagus sehinggga memicu permintaan saham oleh investor dan peningkatan pada tingkat pembayaran dividen dianggap sebagai sinyal yang akan memberi keuntungan, maka sesuai dengan teori sinyal, hal tersebut dapat memberikan sinyal-sinyal baik (good news) kepada publik sehingga akan dapat menaikkan nilai perusahaan yang dapat tercermin dari harga saham perusahaan tersebut.

Implikasi praktis dari penelitian iniadalah dapat memberikan kontribusi positif bagi semua pihak khususnya perusahaan dan pengguna utama laporan keuangan. Bagi perusahaan, penelitian ini dapat memberikan referensi tambahan mengenai pencapaian nilai perusahaan yang maksimal dengan meningkatkan profit dan meningkatkan pembayaran dividen. Bagi pengguna utama laporan keuangan seperti investor, penelitian ini dapat memberikan informasi untuk bahan pertimbangan dalam melakukan investasi.

\section{SIMPULAN}

Berdasarkan hasil penelitian yang telah diperoleh melalui pengujian statistik dan pembahasan yang telah diuraikan, maka dapat disimpulkan sebagai berikut. Profitabilitas berpengaruh positif terhadap nilai perusahaan. Hal ini berarti bahwa semakin tinggi profitabilitas maka semakin tinggi produktivitas aset dalam memperoleh keuntungan bersih. Kebijakan utang tidak berpengaruh terhadap nilai perusahaan. Hal ini berarti bahwa besar kecilnya penggunaan utang yang dilakukan sebagai sumber pembiayaan bagi perusahaan untuk membiayai kegiatan operasional perusahaan tidak akan memengaruhi nilai perusahaan.Kebijakan dividen berpengaruh positif terhadap nilai perusahaan. Hal ini berarti bahwa semakin tinggi tingkat pembayaran dividen maka akan menjadi sinyal bagi investor bahwa manajemen perusahaan memiliki keyakinan akan terjadi peningkatan laba di masa mendatang.

Berdasarkan hasil dan simpulan penelitian, maka saran yang dapat diberikan adalah sebagai berikut. Bagi pihak manajemen perusahaan yang ingin meningkatkan nilai perusahaan dan memperoleh laba secara maksimal dalam bentukdividen maka perlu mempertahankan dan memaksimalkan nilai dari variabel Dividend Payout Ratio (DPR), dan Return on Assets (ROA). Bagi para investor yang mengambil keputusan melakukan investasi sebaiknya investor 
mempertimbangkan nilai dari variabelDividend Payout Ratio (DPR), dan Return on Assets (ROA). Bagi peneliti selanjutnya yang tertarik untuk melakukan penelitian sejenis, disarankan untuk meneliti dengan variabel yang berbeda yang dapat berpengaruh pada nilai perusahaan sektor pertambangan dan disarankan untuk meneliti pengaruh variabel kebijakan utang pada nilai perusahaan sektor pertambangan secara lebih mendalam agar mendapatkan hasil yang lebih akurat.

\section{REFERENSI}

Aharony, J. dan Swary, I. (1980). Quarterly Dividend and Earnings Announcements and Stockholder's Returns: An Empirical Analysis. The Journal ofFinance, 35(1), 1-12. https://doi.org/10.1111/j.15406261.1980.tb03466.x

Andawasatya, R., Indrawati, N. K. and Aisjah, S. (2017). The Effect of Growth Opportunity, Profitability, Firm Size to Firm Value through Capital Structure (Study at Manufacturing Companies Listed On the Indonesian Stock Exchange). Imperial Journal of Interdisciplinary Research, 3(2), 18871894.

Bhattacharya, S. (1979). Imperfect Information, Dividend Policy, and "The Bird in The Hand" Fallacy. The Bell Journal of Economics, 10, 259-270.

Birjandi, Hamid, Behruz Hakemi, and Mohammad Mehdi Molla Sadeghi. (2015). The Study Effect Agency Theory and Signaling Theory on The Level of Voluntary Disclosure of Listed Companies in Tehran Stock Exchange. Research Journal of Finance and Accounting, 6(1), 174-183.

Budagaga, A. (2017). Dividend payment and its impact on the value of firms listed on Istanbul stock exchange: A residual income approach. International Journal of Economics and Financial Issues, 7(2), 370-376.

Chandra, K., Fachrudin, and Sadalia, I. (2017). The Effect of Capital Structure, Profitability and Dividend Policy on Intrinsic Value of Firm. Journal of Finance and Accounting, 8(14), 101-107.

Chung, Kee H and Pruitt, Stephen W. (1994). A Simple Approximation of Tobin's Q. Financial Management, 23(3), 70-74. https://doi.org/10.2307/3665623.

Cortez, Michael Angelo and Stevie Susanto. (2012). The Determinants Of Corporate Capital Structure: Evidence From Japanese Manufacturing Companies. Journal of International Business Research, 11(3), 121-133.

Dewi, Ayu Sri Mahatma dan Wirajaya, Ary. (2013). Pengaruh Struktur Modal, Profitabilitas Dan Ukuran Perusahaan Pada Nilai Perusahaan. E-Jurnal Akuntansi Universitas Udayana, 4(2),358-372.

Dewi, Putu Riska Amanda dan Putri, IGAM Asri Dwija. (2017). Pengaruh Kebijakan Dividen pada Nilai Perusahaan Dengan Pengungkapan CSR dan Good Corporate Governance sebagai Pemoderasi. E-Jurnal Akuntansi Universitas Udayana, 21(1), 173-199.

Dewi, Luh Putu Utami Kartika dan Wirasedana, I Wayan Pradnyantha. (2018). Pengaruh Keputusan Investasi, Keputusan Pendanaan, Kebijakan Dividen dan Tingkat Inflasi Terhadap Nilai Perusahaan. E-Jurnal Akuntansi Universitas Udayana, 23(2), 813-841. https://doi.org/10.24843/EJA.2018.v23.i02.p01. 
Ellili, Nejla Ould Daoud. (2011). Ownership Structure, Financial Policy and Performance of the Firm: US Evidence. International Journal of Business and Management, 6(10). http://dx.doi.org/10.5539/ijbm.v6n10p80.

Fama, dan K. R. French. (1998). Taxes, Financing Decision, and Firm Value. The Journal of Finance, LIII, 819-843. https:/ / doi.org/10.1111/0022-1082.00036.

Gordon and Lintner. (1956). Distribution Of Incomes Of Corporations Among Dividens, Retained Earnings and Taxes. The American Economic Review, 46, 97-113. https:// doi.org/10.1126/science.151.3712.867-a.

Hasnawati, S. (2005). Implikasi Keputusan Investasi, Pendanaan, dan Dividen Terhadap Nilai Perusahaan Publik di Bursa Efek Jakarta. Usahawan, 9, 33-41.

Herawati, Titin. (2013). Pengaruh Kebijakan Dividen, Kebijakan Utang dan Profitabilitas Terhadap Nilai Perusahaan. Jurnal Manajemen, 2(2).

Hermuningsih, Sri. (2013) Pengaruh Profitabilitas, Growth Opportunity, Sruktur Modal Terhadap Nilai Perusahaan Pada Perusahaan Publik di Indonesia. Buletin Ekonomi Moneter dan Perbankan, 16(2), 127-148. https://doi.org/10.1177/027046769801800106.

Indasari, Ade Pratiwi dan Yadnyana, I Ketut. (2018). Pengaruh Profitabilitas, Growth Opportunity, Likuiditas, Dan Struktur Modal Pada Nilai Perusahaan. E-Jurnal Akuntansi Universitas Udayana, 22(1), 714-746. https://doi.org/10.24843/EJA.2018.v22.i01.p27.

Jensen, M.C., dan W.H. Meckling. (1976).Theory of the Firm: Managerial Behavior Agency costs and Capital Structure. Journal of Financial Economics, 305-360.

Mahendra, A., Sri artini, L. Gede dan Suarjaya, A. G. (2012). Pengaruh Kinerja Keuangan Terhadap Nilai Perusahaan di Bursa Efek Indonesia. Jurnal Manajemen, Stategi Bisnis, dan Kewirausahaan, 6(2), 130-138.

Mardasari, Rizky Budi. (2014). Pengaruh Insider Ownership, Kebijakan Utang, dan Free Cash Flow terhadap Nilai Perusahaan melalui Kebijakan Dividen. Jurnal Ilmu Manajemen, 2(4).

Marlina, Lisa dan Clara Danica. (2009). Analisis Pengaruh Cash Position, Debt to Equity Ratio dan Return on Asset Terhadap Dividend Payout Ratio. Jurnal Manajemen Bisnis, 2(1), 1-6.

Miller, Merton H dan Modigliani, Franco. (1961). Dividend Policy, Growth, and the Valuation of Shares. Chicago Journals, 34(4), 411-433.

Myers, Stewart C. (2001). Capital Structure. Journal of Economic Perspective, 15(2), 81-102. https:// doi.org/10.1257/jep.15.2.81.

Nasehah, Widyarti. (2012). Analisis Pengaruh ROE, DER, DPR, Growth Dan Firm Size Terhadap Price To Book Value (PBV) (Studi Kasus pada Perusahaan yang Listed di BEI Periode Tahun 2007- 2010). Diponegoro Journal of Management,1(1).

Nurfauziah.N., Harjito, D. A. dan Ringayati, A. (2006). Hubungan Kebijakan Utang, Insider Ownership dan Kebijakan Dividen dalam Mekanisme Pengawasan Masalah Agensi di Indonesia. Jurnal Akuntansi dan Auditing Indonesia, 10(2), 121-136.10.20885/ sinergi.vol9.iss2.art2.

Octaviani, Ni Kadek Dewi dan Astika, Ida Bagus Putra. (2016). Profitabilitas Dan Leverage Sebagai Pemoderasi Pengaruh Kebijakan Dividen Pada Nilai Perusahaan. E-Jurnal Akuntansi Universitas Udayana, 14(3), 2192-2219. 
Oladipupo, A.O and Okafor, C.A. (2013). Relative Contribution of Working Capital Management to Corporate Profitability and Dividend Payout Ratio: Evidence from Nigeria. International Journal of Business and Finance Management Research, 1(1), 11-20.

Pertiwi, Putri Juwita., Parengkuan Tommy, dan Johan R. Tumiwa. (2016). Pengaruh Kebijakan Hutang, Keputusan Investasi Dan Profitabilitas terhadap Nilai Perusahaan Food And Beverages Yang Terdaftar di Bursa Efek Indonesia. Jurnal Riset Ekonomi, Manajemen, Bisnis dan Akuntansi, 4(1), 1369-1380.

Pratama, I Gede Gora Wira dan Wirawati, Ni Gusti Putu. (2016). Pengaruh Struktur Modal Dan Profitabilitas Terhadap Nilai Perusahaan Dengan Kepemilikan Manajerial Sebagai Pemoderasi. E-Jurnal Akuntansi Universitas Udayana, 15(3), 1796-1825.

Pratiwi, Ni Putu Diah dan Mertha, Made. (2017). Pengaruh Kebijakan Utang Dan Profitabilitas Pada Nilai Perusahaan Dengan Kebijakan Dividen Sebagai Variabel Pemoderasi. E-Jurnal Akuntansi Universitas Udayana, 20(2), 14461475.https://doi.org/10.1038/srep44329.

Rahmawati, Apriliana Nuzul. (2012). Analisis Faktor Kebijakan Utang yang Mempengaruhi Nilai Perusahaan (Studi Pada Perusahaan Yang Terdaftar di BEI Periode 2006-2010). Jurnal Fakultas Ekonomi dan Bisnis Universitas Diponegoro.

Reni, Yendrawati dan Pratiwi, R. (2015). Relevansi Nilai Informasi Laba dan Arus Kas Terhadap Harga Saham. Jurnal Dinamika Manajemen, 5(2), 161-170. https://doi.org/10.15294/jdm.v5i2.3658.

Rosi, Setiana. (2012). Pengaruh Kebijakan Utang, Kebijakan Dividen, Ukuran Perusahaan dan Profitabilitas terhadap Nilai Perusahaan (Studi Empiris Terhadap Perusahaan Food And Beverage Yang Terdaftar di BEI). E-Journal Akuntansi Unila.

Sadia, Ni Made Dwi Safitri dan Sujana, I Ketut. (2017). Pengaruh Kepemilikan Institusional, Manajerial, Free Cash Flow Pada Nilai Perusahaan Dengan Variabel Intervening Kebijakan Utang. E-Jurnal Akuntansi Universitas Udayana, 19(1), 479-507.

Sari, Ni Putu Santhi Puspita dan Wirajaya, I Gde Ary. (2017). Pengaruh Free Cash Flow Dan Risiko Bisnis Pada Nilai Perusahaan Dengan Kebijakan Utang Sebagai Variabel Intervening. E-Jurnal Akuntansi Universitas Udayana, 18(3), 2260-2289.

Sartono, R. Agus. (2010). Manajemen Keuangan Teori dan Aplikasi, Edisi 5. Yogyakarta: BPFE.

Sofyaningsih, S., \& Hardiningsih, P. (2011). Struktur Kepemilikan, Kebijakan Dividen, Kebijakan Utang Dan Nilai Perusahaan. Dinamika Keuangan dan Perbankan, 3(1).

Suartawan, I Gst. Ngr. Putu Adi dan Yasa, Gerianta Wirawan. (2016). Pengaruh Investment Opportunity Set Dan Free Cash Flow Pada Kebijakan Dividen dan Nilai Perusahaan. E-Jurnal Akuntansi Universitas Udayana, 14(3),20142044. https://doi.org/10.24843/jiab.2016.v11.i02.p01. 
Sujoko dan Soebiantoro. (2007). Pengaruh Struktur Kepemilikan Saham, Leverage, Faktor Intern dan Faktor Ekstern Terhadap Nilai Perusahaan. Jurnal Manajemen dan Kewirausahaan, 9(1), 41-48.

Sumanti, Jorenza dan Mangantar, Marjam. (2015). Analisis Kepemilikan Manajerial, Kebijakan Hutang dan Profitabilitas terhadap Kebijakan Deviden dan Nilai Perusahaan pada Perusahaan Manufaktur yang Terdaftar di BEI. Jurnal Riset Ekonomi, Manajemen, Bisnis dan Akuntansi, 3(1), 1141-1151.

Ustiani, Nila. (2014). Pengaruh Struktur Modal, Kepemilikan Manajerial, Keputusan Investasi, Kebijakan Dividen, Keputusan Pendanaan dan Profitabilitas Terhadap Nilai Perusahaan (Studi pada Perusahaan Keuangan dan Perbankan di BEI tahun 2009-2013). Jurnal Ilmiah Mahasiswa S1 Akuntansi Universitas Pandanaran. 